\title{
DISCURSO PRONUNCIADO POR EL PRESIDENTE DEL COLEGIO DE ABOGADOS DE LA REGIÓN DE COQUIMBO, DON MANUEL CORTES BARRIENTOS, EN EL SALON DE PROTOCOLO DEL PALACIO ARZOBISPAL DE LA SERENA, EL 30 DE NOVIEMBRE DE 1995.
}

\section{SEÑORAS Y SEÑORES:}

El Colegio de Abogados de Chile de la Cuarta Región de Coquimbo, se reúne hoy con vuestra gentil presencia, para recordar 70 años de su existencia $y$, a la vez para efectuar un acto de reconocimiento y agradecimiento a nueve de sus más llustres Abogados.

Sea del caso establecer que por mandato de Decreto Ley 406 del año 1925, el Colegio de Abogados de La Serena, nació en su existencia legal con el objeto de regular el ejercicio de la profesión de Abogado, sometiéndose a normas éticas y jurídicas que regulaban su actividad profesional.

Dicho Colegio así nacido "se inspiraba, más que en la defensa de los intereses de sus miembros, en las exigencias de la función social que cumplen, más que en el afán de mantener previlegios, en la necesidad de encuadrar a sus afiliados dentro de las normas de una severa disciplina, más que en la defensa de su propio interés, en la de servir a los de la justicia, a cuyo fin supremo la abogacía se haya vinculada; más que en su propio proyecto, en el de ser útiles dentro de la ley, a los intereses y derechos que tutelan".

Esos conceptos estuvieron largamente presentes en la existencia del Colegio de Abogados de La Serena.

El mismo que naciera a la vida de la mano los señores, cuyos nombres hoy expresamos con respeto los señores Antonio Aguirre Mercado, Fortunato Peralta Jeraldo, Aurelio del Río Nogueira, Ernesto Peñafiel Varela y don Manuel Antonio Pizarro Marín.

La vida institucional del país fue cambiando y, hoy son meras asociaciones gremiales las que buscan llevar a cabo, esas metas y objetivos trazados en el pasado.

De todas ellas, la más importante sin duda es el control de nuestra profesión, que estuviera confiado a los colegios profesionales, y que hoy se encuentra en un área difusa que no ha permitido su eficaz y adecuada acción.

Hay allí una tarea pendiente, que se deriva del propio concepto de la profesión de Abogado que requiere ser reivindicado en las bases mismas de la convivencia social, y los primeros llamados a hacerlo somos nosotros mismos.

En el mundo en que vivimos, la justicia no es virtud de profesionales.

Nuestro mundo de hoy es uno en el cual, los valores y las virtudes que conforman las bases de nuestra civilización cristiano occidental, suelen tambalear ante la embestida violenta de un exitismo que se estructura en el ansia de poseer, en el vértigo del consumir. 
En este universo donde la acción del abogado, se lleva a cabo y es al centro de él, donde el Abogado debe buscar la justicia y la libertad, con la verdad como emblema real y concreto.

La justicia es virtud cívica que caracteriza a los pueblos.

Por ello la anécdota aquella que viene de la Edad Media, refiriendo como en un encuentro entre los magnates y un cardenal, se le preguntaba a éste cuales eran sus poderes, y él abriendo una ventana, y exhibiendo según unos, un ejercito, y según otros sólo su guardia personal, respondía: mis poderes son estos.

Es verdad esos poderes hacen falta, son indispensables cuando se van a la guerra.

Pero cuando no se trata de conquistar dominios, sino de que un núcleo de hombres viva en paz, son benevolencia reciproca, son desevolvimiento de la cultura, son aquietamiento de las pasiones, son estimación común, los Poderes del Estado, son una legislación clara, un Poder Judicial independiente y unos abogados conscientes del deber de servicio a la justicia.

Estas simples disquisiciones en torno a la noble función del abogado se nos asoman hoy con más nitidez, cuando saludamos en sus largos años de ejercicio profesional a Doña Luz Alvarez Madariaga, a Don Hugo Zepeda Barrios, a Don Héctor Carreño Latorre, a Don Manuel Ruiz Aburto Ríoseco, a Don Raúl Parga Muñoz, a Don Hernán Brücher Encina, a Don Renán Fuentealba Moena, a Don Jaime Alvarez Caceres y a Don Raúl Salamanca Jorquera.

Las largas vidas consagradas a la tarea de ser abogados en los tan distintos ámbitos en que han desarrollado su quehacer, es lo que hoy destacamos en esta reunión ampliada, para hacerles participes a todos ustedes de nuestro regocijo y nuestra alegría.

He aquí que debo consignar algunas ideas sobre Don Hugo Zepeda Barrios, el que naciera en el corazón de la Provincia del Limarí, la ciudad de Ovalle., el 1 de junio de 1907.

Estudió en el Liceo de Ovalle y en la Universidad de Chile.

Juró como Abogado ante el Tribunal Supremo el 13 de noviembre de 1928.

Su memoria para optar al título, versó sobre el delincuente pasional.

Vino al Puerto de Coquimbo a ejercer en forma liberal, formando un estudio jurídico que atendía a las más importantes personas naturales y jurídicas de la antigua Provincia de Coquimbo.

Militante del Partido Liberal, fue elegido Diputado el año 1932, siendo reelegido en la Cámara Baja en múltiples oportunidades, hasta elegido Senador por la agrupación Provincial de Atacama y Coquimbo, correspondientes a la Tercera y Cuarta Región actual.

En el desempeño Parlamentario fue integrante de diversas comisiones en la Cámara Alta, llegando a ser elegido Presidente del Senado de la República, cargo que ejerciera con dignidad y decoro, los mismos con que ha llevado a cabo los distintos cargos que, en su vida profesional y de diversa índole, le ha tocado desempeñar. hijos.

Fue casado con la señora Anita Coll y de ese feliz matrimonio, nacieron cuatro 
Está por cumplir en pocos días mas, 67 años de título profesional y su vida como tal, esta casi ligada desde su creación con el Colegio de Abogados de La Serena y con está región, de sus ancestros y de su progenie.

Saludamos en Don Hugo Zepeda Barrios, a uno de los más ilustres y distinguidos abogados de nuestro país, sintiéndonos regocijados de ser en esta ocasión, portadores de un homenaje que es acto de reconocimiento al hombre público que ha honrado con sus actos y su persona, la muy noble profesión de abogado.

Por todo ello, por su vida y su tarea, Don Hugo, muchas gracias.

Gracias que le da el Colegio de Abogado de la Cuarta Región, su terreno de origen al que Ud. representara, y que hoy no hace sino expresar un sentimiento de gratitud real y concreto.

Una reflexión tras lo dicho a Don Hugo Zepeda Barrios, con nuestro sentimiento, nuestra emoción, y nuestra alegría.

Una alegría que surge entre el alma a veces requerida por la desilusión, un espíritu tal vez escéptico ante el dolor de algún fracaso o por la angustia de la tarea aún no realizada, en suma por estímulos negativos que aparecen en nuestra vida.

Pues bien en tales condiciones nada hay de más inefable consuelo encontrar un grupo de hombres en los que no se ha apagado la antorcha de la fe, ni se han secado las fuentes de la cordialidad, en una común tarea de ser abogado.

Muchas Gracias. 